\title{
Selenium source and level on performance, selenium retention and biochemical responses of young broiler chicks
}

Pedro Righetti Arnaut ${ }^{1}$, Gabriel da Silva Viana ${ }^{2 *}$, Lucimauro da Fonseca', Warley Junior Alves', Jorge Cunha Lima Muniz ${ }^{1}$, James Eugene Pettigrew ${ }^{3}$, Fabyano Fonseca e Silva ${ }^{1}$, Horácio Santiago Rostagno ${ }^{1}$ and Melissa Izabel Hannas ${ }^{1}$

\begin{abstract}
Background: Selenium (Se) has been recognized as an essential micronutrient for nearly all forms of life. In recent decades, broiler responses to dietary Se supplemental levels and sources have received considerable attention. On environmental grounds, organic trace mineral utilization in practical broiler feeds has been defended due to its higher bioavailability. In such feeds, trace minerals are provided simultaneously in the same supplement as inorganic salts or organic chelates, a fact commonly ignored in assays conducted to validate organic trace mineral sources. The current assay aimed to investigate growth and biochemical responses, as well as Se retention of growing chicks fed diets supplemented with organic and inorganic Se levels and where the trace minerals (zinc, copper, manganese, and iron) were provided as organic chelates or inorganic salts according to Se source assessed. In so doing, a $2 \times 5$ factorial arrangement was used to investigate the effects of sodium selenite (SS) and seleniumyeast (SY) supplemented in feeds to provide the levels of $0,0.08,0.16,0.24$, and $0.32 \mathrm{mg} \mathrm{Se} / \mathrm{kg}$.

Results: Chicks fed selenium-yeast diets had body weight (BW), and average daily gain (ADG) maximized at 0.133 and $0.130 \mathrm{mg} \mathrm{Se} / \mathrm{kg}$, respectively. Both Se sources linearly increased $(P<0.05)$ the glutathione peroxidase (GSH-Px) activity in chick blood but higher values were observed in sodium selenite fed chicks $(P<0.05)$. Both Se sources influenced thyroid hormone serum concentrations $(P<0.05)$. Chicks fed SY exhibited greater retention of Se in the feathers $(P<0.05)$. Relative bioavailability of selenium yeast compared with $\mathrm{SS}$ for the Se content in carcass, feathers, total and Se retention were, 126, 116, 125 and 125\%, respectively. SY supplementation resulted in lower liver Se concentration as Se supplementation increased $(P<0.05)$.
\end{abstract}

Conclusions: Based on performance traits, the supplemental level of organic Se as SY in organic trace minerals supplement to support the maximal growth of broiler chicks is $0.133 \mathrm{mg} \mathrm{Se} / \mathrm{kg}$.

Keywords: Glutathione peroxidase, Organic trace minerals, Selenium balance, Selenium yeast, Tissue mineralization

\footnotetext{
* Correspondence: gabriel.viana@luke.fi

${ }^{2}$ Production Systems, Natural Resources Institute Finland (Luke), 31600 Jokioinen, Finland

Full list of author information is available at the end of the article
}

(c) The Author(s). 2021 Open Access This article is licensed under a Creative Commons Attribution 4.0 International License, which permits use, sharing, adaptation, distribution and reproduction in any medium or format, as long as you give appropriate credit to the original author(s) and the source, provide a link to the Creative Commons licence, and indicate if changes were made. The images or other third party material in this article are included in the article's Creative Commons licence, unless indicated otherwise in a credit line to the material. If material is not included in the article's Creative Commons licence and your intended use is not permitted by statutory regulation or exceeds the permitted use, you will need to obtain permission directly from the copyright holder. To view a copy of this licence, visit http://creativecommons.org/licenses/by/4.0/ The Creative Commons Public Domain Dedication waiver (http://creativecommons.org/publicdomain/zero/1.0/) applies to the data made available in this article, unless otherwise stated in a credit line to the data. 


\section{Background}

Selenium (Se) has been recognized as an essential trace element for all forms of animal life. In avian species, Se is required for the synthesis of selenocysteine (Se-Cys), an amino acid present in selenoproteins of biological importance in poultry metabolism such as glutathione peroxidase (GSH-Px), thioredoxin reductase, and iodothyronine deiodinase family [1]. Whereas the first two selenoenzymes modulate antioxidant defenses against reactive oxygen species (ROS) which may damage cell functioning [2-5], the latter family of enzymes participates on thyroid metabolism by converting thyroxin (T4) into triiodothyronine (T3), a hormone involved in the metabolism of proteins, carbohydrates and lipids [6-10]. Even though Se deficiency has been associated with metabolic disorders [11-16], the extent to which chick growth is affected by dietary Se supplementation has been a matter of discussion amongst poultry nutritionists. Previous research findings have demonstrated no effects of Se supplementation on broiler growth performance [3, 17-19], suggesting, therefore, that cereal-based diets could provide the amounts of Se required for physiological needs.

Indeed, cereals utilized in practical feeds contain Se, being $50 \%$ found as selenomethionine (Se-Met); however, because Se content of plant cereals are affected by Se content in the soil, the poultry industry supplements Se to avoid nutritional deficiencies $[1,20]$. NRC [21] describe Se requirements as $0.15 \mathrm{mg} \mathrm{Se} / \mathrm{kg}$ which was later suggested by Wang et al. [10]. Conversely, Cai et al. [18] and Cemin et al. [22] recommended the supplemental levels of 0.30 and $0.75 \mathrm{mg} \mathrm{Se} / \mathrm{kg}$, respectively. When considering that fast growth genotypes currently raised exhibit higher metabolic rates, and may, therefore, be more susceptible to ROS production, higher amounts of Se are expected to be required to ensure quality chicken meat $[18,23]$. Conventionally, Se is supplemented in diets either as inorganic salts such as sodium selenite (SS) or as the organic form of selenium enriched-yeast (SY), which is majorly composed of Se-Met [24]. Because Se present in the selenium yeast is in an organic structure, it is considered less toxic, more digestible, retained and bioavailable than the SS $[2,4,19,25,26]$.

As well as Se, other trace minerals provided as organic sources are more bioavailable than inorganic sources. When supplied in practical diets, SS is typically used in supplements with inorganic sources of other trace minerals; meanwhile selenium yeast is typically used with organic sources of other trace minerals. In case interactions among minerals may be affected by the form of the dietary minerals, it seems appropriate to assess the optimal dietary concentrations of supplemental selenium for use by the poultry industry in the dietary environment in which each selenium source will typically be used in practice, inorganic selenium with other inorganic trace minerals and organic selenium with other organic trace minerals. We conducted the current study to determine the effect of levels and sources of Se provided by organic and inorganic trace mineral supplements on performance, Se retention and physiological responses of young broiler chicks.

\section{Results}

The analyzed concentrations of Se in SS supplemented diets were $0.123,0.192$. $0.245,0.356$ and $0.428 \mathrm{mg} \mathrm{Se} / \mathrm{kg}$, whereas the concentration in the diets supplemented with SY were 0.131, 0.213, 0.271, 0.350, $0.418 \mathrm{mg} \mathrm{Se} / \mathrm{kg}$. These values for Se agree with the calculated values for both sources of $0.138,0.218,0.298,0.378$ and $0.458 \mathrm{mg}$ of $\mathrm{Se} / \mathrm{kg}$.

\section{Growth performance}

No interactions were observed between the micromineral source (inorganic or organic) and Se level $(P>0.05)$ in any of the variables measured in this experiment. There were no main effects of micromineral source on measures of growth performance. Considering data from both sources, the supplemented levels of Se affected $(P<0.05)$ both BW and ADG (Table 1$)$, but the pattern of response was not described by a quadratic regression. The broiler chicks receiving a diet with $0.160 \mathrm{mg} \mathrm{Se} / \mathrm{kg}$ as SY and organic trace minerals showed higher BW $(P<0.05)$, ADG $(P<0.05)$ and ADFI $(P<0.05)$ compared with the SS and inorganic trace minerals at the same supplementation level. Among the SY treatments, the highest values for BW and ADG were at intermediate dietary Se levels (quadratic: $P=0.088$ for BW, 0.093 for ADG), (Table 1), and the optimal supplementation levels were estimated at 0.133 and $0.130 \mathrm{mg} \mathrm{Se} / \mathrm{kg}$, respectively, through the derivative of the fitted polynomial quadratic models $\mathrm{BW}_{(\mathrm{SY})}=-501.8 \mathrm{x}^{2}+133.2 \mathrm{x}+500.5, \quad r^{2}=0.08$, and $\mathrm{ADG}_{(\mathrm{SY})}=-48.4899 \mathrm{x}^{2}+12.6437 \mathrm{x}+32.0393, r^{2}=$ 0.08. The FC increased linearly $(P<0.05)$ as SY supplementation increased. A lower BW $(P<0.05)$ and ADG $(P<0.05)$ were found for SY supplementation at $0.32 \mathrm{mg}$ $\mathrm{Se} / \mathrm{kg}$ when compared with $0.16 \mathrm{mg} \mathrm{Se} / \mathrm{kg}$, and FC increased linearly $(P<0.05)$ with increasing levels of SY supplementation. As the level of SS supplementation increased, ADG tended to respond quadratically, but the pattern of response differed $(P<0.05)$ from the response to $S Y$ level, which reached maximum at $0.16 \%$ supplemental Se. The ADFI tended $(P=0.090)$ to decline linearly as dietary level of SS increased. A low incidence of mortality was noticed throughout the trial: one chick fed $0.16 \mathrm{mg} \mathrm{Se} / \mathrm{kg}$ in the diet supplemented with SS, and other bird fed $0.08 \mathrm{mg} \mathrm{Se} / \mathrm{kg}$ in the diet supplemented with SY. 
Table 1 Effects of dietary selenium levels and sources on performance traits of 17-d-old broiler chickens

\begin{tabular}{|c|c|c|c|c|c|c|c|c|c|c|c|c|}
\hline \multirow{2}{*}{$\begin{array}{l}\text { Selenium } \\
\text { source }^{1}\end{array}$} & \multicolumn{5}{|c|}{ Selenium levels, $\mathrm{mg} / \mathrm{kg}$} & \multirow[t]{2}{*}{ Means } & \multirow[t]{2}{*}{ SEM $^{2}$} & \multicolumn{5}{|l|}{ P-Value } \\
\hline & 0.0 & 0.08 & 0.16 & 0.24 & 0.32 & & & Source & Level & $S \times L^{3}$ & $\mathrm{~L}^{4}$ & $Q^{5}$ \\
\hline \multicolumn{13}{|c|}{ Initial weight, g/bird } \\
\hline SS & 180.4 & 180.4 & 180.5 & 180.3 & 180.4 & 180.4 & 0.038 & 0.478 & 0.999 & - & - & - \\
\hline SY & 180.2 & 180.3 & 180.1 & 180.3 & 180.2 & 180.2 & & & & & & \\
\hline \multicolumn{13}{|c|}{ Body weight, g/bird } \\
\hline Means & 510 & 490 & 508 & 502 & 494 & & 6.84 & 0.432 & 0.019 & 0.144 & 0.180 & 0.977 \\
\hline SS & 514 & 487 & $497 b$ & 500 & 498 & 499 & & & & & 0.378 & 0.104 \\
\hline SY & $506 \mathrm{AB}$ & $492 \mathrm{AB}$ & $521 \mathrm{Aa}$ & $502 \mathrm{AB}$ & $490 \mathrm{~B}$ & 502 & & & & & 0.308 & 0.088 \\
\hline \multicolumn{13}{|c|}{ Average daily gain, g/bird/day } \\
\hline Means & $32.9 \mathrm{~A}$ & $31.0 \mathrm{~B}$ & $32.9 \mathrm{AB}$ & $32.1 \mathrm{AB}$ & $31.4 \mathrm{AB}$ & & 0.672 & 0.429 & 0.017 & 0.132 & 0.165 & 0.977 \\
\hline SS & 33.3 & 30.7 & $31.6 b$ & 31.9 & 31.7 & 31.9 & & & & & 0.366 & $0.097^{\mathrm{e}}$ \\
\hline SY & $32.6 A B$ & $31.3 \mathrm{~B}$ & $34.1 \mathrm{Aa}$ & $32.2 A B$ & $30.9 \mathrm{~B}$ & 32.2 & & & & & 0.283 & $0.093^{f}$ \\
\hline \multicolumn{13}{|c|}{ Average daily feed intake, $g / b i r d / d a y$} \\
\hline Means & 47.3 & 45.5 & 47.2 & 46.4 & 45.9 & & 0.790 & 0.661 & 0.122 & 0.107 & 0.847 & 0.160 \\
\hline SS & $48.5 \mathrm{a}$ & 45.6 & $46.1 \mathrm{~b}$ & 46.4 & 46.0 & 46.6 & & & & & 0.090 & 0.122 \\
\hline SY & $46.0 \mathrm{~b}$ & 45.3 & $48.2 \mathrm{a}$ & 46.4 & 45.8 & 46.3 & & & & & 0.847 & 0.160 \\
\hline \multicolumn{13}{|c|}{ Feed conversion rate, $g / g$} \\
\hline Means & 1.43 & 1.45 & 1.45 & 1.45 & 1.47 & & 0.015 & 0.238 & 0.185 & 0.335 & 0.018 & 0.809 \\
\hline SS & 1.44 & 1.46 & 1.46 & 1.46 & 1.45 & 1.46 & & & & & 0.661 & 0.449 \\
\hline SY & $1.42 \mathrm{~B}$ & $1.44 \mathrm{AB}$ & $1.44 \mathrm{AB}$ & $1.44 \mathrm{AB}$ & $1.48 \mathrm{~A}$ & 1.44 & & & & & 0.004 & 0.616 \\
\hline
\end{tabular}

${ }^{1}$ SS sodium selenite, $S Y$ selenium enriched-yeast

${ }^{2}$ Standard error of means

${ }^{3}$ Interactive effects between selenium and trace minerals sources and selenium levels

${ }^{4}$ Linear effect of supplementation selenium levels

${ }^{5}$ Quadratic effect of supplementation selenium levels

A-B Different uppercase letters in the same line and lowercase letters in the same column are different by Tukey test at $5 \%$

ef Different superscripts letter indicates difference in the orthogonal contrasts between equations

\section{Enzyme activity and hormone concentrations}

As shown in Table 2, inorganic trace minerals resulted in higher values of GSH-Px activity in the serum over all Se levels $(P<0.01)$ and at $0.24 \mathrm{mg}$ added $\mathrm{Se} / \mathrm{kg}$ compared to organic trace minerals. GSH-Px activity in the blood of broiler chicks rose linearly $(P<0.05)$ as supplemented Se level from either source increased (Table 2). There were no treatment effects on superoxide dismutase concentrations. Considering both sources together, Se levels affected free T4 (fT4) and tended to affect the total T3 concentration $(P=0.056)$ and free T3:free T4 $(P=0.078)$, but the patterns of response were not described by quadratic regression. There was a quadratic response $(P<0.05)$ in total T3 concentration with the greatest value where no SS was added. In SS and inorganic trace mineral supplemented group, chicks fed 0.08 $\mathrm{mg} \mathrm{Se} / \mathrm{kg}$ had the lowest T3 concentration $(P<0.05)$ compared with not supplemented group, but did not differ from birds fed 0.16, 0.24, and $0.32 \mathrm{mg} \mathrm{Se} / \mathrm{kg}$ diet. Differences between mineral sources in the T3 concentration were observed only when no Se was added to the diets $(P<0.05)$, with the inorganic minerals having higher T3. A trend $(P=0.089)$ in the interactive effects of Se levels and sources occurred in the free T3 (fT3) concentration in the serum, with a higher value for the organic treatment at only $0.16 \mathrm{mg} \mathrm{Se} / \mathrm{kg}$. The fT3 concentration in broiler chicks fed SY and organic trace microminerals tended to respond quadratically to increased Se supplementation $(P=0.091)$ with maximum value at $0.16 \mathrm{mg} \mathrm{Se} / \mathrm{kg}$ diet. A quadratic $(P<0.05)$ or trend to quadratic $(P=0.057)$ change in free T4, was observed in the blood of birds fed SS and SY, respectively, with the highest values at $0.16 \mathrm{mg} \mathrm{Se} / \mathrm{kg}$ diet. A linear increase $(P=0.037)$ in the free T3 to free T4 ratio occurred with SY supplementation.

\section{Se balance}

A linear response $(P<0.01)$ was observed for the main effects of Se Intake (SeI), Se Carcass $(\mathrm{SeC})$, Total Se $(\mathrm{SeT})$ and Se Retention (SeR) (Table 3) as supplemental Se levels changed, regardless of Se source. A linear increase $(P<0.01)$ and quadratic response $(P<0.01)$ with steeper response at low Se intakes was observed for SeF with increasing Se supplementation levels. A quadratic 
Table 2 Effects of dietary selenium levels and sources on blood parameters of 17-d-old broiler chickens

\begin{tabular}{|c|c|c|c|c|c|c|c|c|c|c|c|c|}
\hline \multirow{2}{*}{$\begin{array}{l}\text { Selenium } \\
\text { source }^{1}\end{array}$} & \multicolumn{5}{|c|}{ Selenium levels, mg/kg } & \multirow[t]{2}{*}{ Means } & \multirow[t]{2}{*}{ SEM $^{2}$} & \multicolumn{5}{|l|}{ P-value } \\
\hline & $\overline{0.0}$ & 0.08 & 0.16 & 0.24 & 0.32 & & & Source & Level & $S \times L^{3}$ & $\mathrm{~L}^{4}$ & $Q^{5}$ \\
\hline \multicolumn{13}{|c|}{ Glutathione peroxidase, U/L } \\
\hline Means & $79.1 \mathrm{D}$ & $153 \mathrm{C}$ & $216 \mathrm{BC}$ & $266 \mathrm{AB}$ & $319 \mathrm{~A}$ & & 24.3 & $<0.01$ & $<0.01$ & 0.121 & $<0.01$ & 0.406 \\
\hline SS & $93.8 \mathrm{C}$ & $165 \mathrm{BC}$ & $240 A B$ & $335 \mathrm{Aa}$ & $334 \mathrm{~A}$ & 233 & & & & & $<0.01^{\mathrm{e}}$ & 0.174 \\
\hline SY & $62.8 \mathrm{C}$ & $126 \mathrm{BC}$ & 194 B & $198 \mathrm{Bb}$ & $304 \mathrm{~A}$ & 183 & & & & & $<0.01^{\mathrm{e}}$ & 0.904 \\
\hline \multicolumn{13}{|c|}{ Superoxide dismutase, $U / L$} \\
\hline Means & 98.7 & 88.9 & 92.1 & 81.9 & 92.9 & & 7.17 & 0.524 & 0.647 & 0.394 & 0.647 & 0.243 \\
\hline SS & 98.5 & 86.4 & 91.8 & 88.0 & 93.4 & 91.6 & & & & & 0.887 & 0.187 \\
\hline SY & 98.9 & 91.5 & 92.5 & 75.8 & 92.3 & 90.2 & & & & & 0.420 & 0.549 \\
\hline \multicolumn{13}{|c|}{ Total T3, ng/ml } \\
\hline Means & 3.32 & 2.30 & 3.01 & 2.51 & 2.73 & & 0.125 & 0.419 & 0.056 & 0.134 & 0.278 & 0.241 \\
\hline SS & $3.99 \mathrm{Aa}$ & $2.41 \mathrm{~B}$ & $3.39 A B$ & $2.59 A B$ & $2.84 A B$ & 2.87 & & & & & 0.136 & 0.018 \\
\hline SY & $2.76 \mathrm{~b}$ & 2.16 & 2.75 & 2.45 & 2.59 & 2.68 & & & & & 0.816 & 0.682 \\
\hline \multicolumn{13}{|c|}{ Free $T 3, \mathrm{ng} / \mathrm{ml}$} \\
\hline Means & 0.0056 & 0.0045 & 0.0059 & 0.0059 & 0.0054 & & 0.0002 & 0.336 & 0.270 & 0.089 & 0.344 & 0.786 \\
\hline SS & 0.0060 & 0.0042 & $0.0050 \mathrm{~b}$ & 0.0060 & 0.0055 & 0.0053 & & & & & 0.648 & 0.163 \\
\hline SY & $0.0052 A B$ & 0.0048 B & $0.0068 \mathrm{Aa}$ & $0.0059 A B$ & $0.0053 A B$ & 0.0056 & & & & & 0.343 & 0.091 \\
\hline \multicolumn{13}{|c|}{ Free $T 4, \mathrm{ng} / \mathrm{ml}$} \\
\hline Means & 31.6 & 36.4 & 38.8 & 32.9 & 35.9 & & 0.942 & 0.416 & 0.050 & 0.403 & 0.627 & 0.140 \\
\hline SS & 34.0 & 37.5 & 42.7 & 34.5 & 37.5 & 35.2 & & & & & 0.604 & $0.048^{\circ}$ \\
\hline SY & 29.3 & 36.0 & 37.2 & 31.0 & 34.3 & 36.6 & & & & & 0.805 & $0.057^{6}$ \\
\hline \multicolumn{13}{|c|}{ Free T3:Free $T 4^{6}$} \\
\hline Means & 1.58 & 1.35 & 1.44 & 1.87 & 1.72 & & 0.226 & 0.230 & 0.078 & 0.735 & 0.070 & 0.125 \\
\hline SS & 1.60 & 1.36 & 1.28 & 1.79 & 1.53 & 1.51 & & & & & 0.575 & 0.531 \\
\hline SY & 1.56 & 1.34 & 1.59 & 1.95 & 1.91 & 1.67 & & & & & 0.037 & 0.451 \\
\hline $\begin{array}{l}1 \text { SS sodiun } \\
{ }^{2} \text { Standard } \\
{ }^{3} \text { Interactiv } \\
{ }^{4} \text { Linear eff } \\
{ }^{5} \text { Quadrati } \\
{ }^{6} \text { Free T3:F } \\
{ }^{\text {A-B Differer }}\end{array}$ & $\begin{array}{l}\text { ite, SY sel } \\
\text { f means } \\
\text { ts betwee } \\
\text { suppleme } \\
\text { of supple } \\
\times 10000\end{array}$ & $\begin{array}{l}\text { Im enriche } \\
\text { lenium an } \\
\text { ion selenic } \\
\text { ttation sel }\end{array}$ & $\begin{array}{l}\text { east } \\
\text { ace minera } \\
\text { evels } \\
\text { um levels }\end{array}$ & 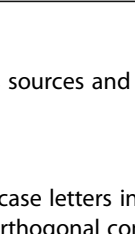 & enium level & & & & & & & \\
\hline
\end{tabular}

increase $(P<0.01)$ was verified for SeF with SY supplementation and organic trace minerals, and, according to the fitted polynomial quadratic model $\mathrm{SeF}_{(\mathrm{SY})}=-$ $0.2641 x^{2}+0.1824 x+0.0245, r^{2}=0.26$, the maximum Se retention in the feathers was estimated at the dietary supplemental Se concentration of $0.30 \mathrm{mg} \mathrm{Se} / \mathrm{kg}$. The lowest supplemental levels of Se in feeds that promoted maximum SeF were 0.16 and $0.08 \mathrm{mg} \mathrm{Se} / \mathrm{kg}$ for birds fed SS $(P<0.05)$ and SY $(P<0.05)$, respectively. When a comparison is made between not supplemented group and SY supplemented chicks, greater SeR in was observed at 0.16 and $0.32 \mathrm{mg} \mathrm{Se} / \mathrm{kg}$ in birds fed SS $(P<$ $0.05)$, meanwhile in the SY fed chicks, SeR was higher at 0.24 and $0.32 \mathrm{mg} \mathrm{Se} / \mathrm{kg}(P<0.05)$. A trend $(P=0.075)$ for a linearly decreased response was observed in the SeBal with the increasing Se levels.
Se concentration in tissue

Se concentration in the liver showed a trend $(P=0.073)$ to a linear decrease with increased Se supplementation levels when considering both Se sources combined (Table 4). A linear reduction in the Se concentration in the liver was observed $(P<0.05)$ with increasing SY supplemented levels and organic trace minerals. Neither the Se sources nor levels influenced the Se concentration in the broiler breast muscle $(P>0.05)$.

\section{Relative bioavailability estimates}

Multiple linear regression equations were not utilized to evaluate the relative bioavailability in this experiment because the basal diets were different, with different mineral sources, so it would be invalid to force a common intercept. Significant $(P<0.05) \quad$ linear regression 
Table 3 Effects of dietary selenium levels and sources on selenium balance on 17-d-old broiler chickens

\begin{tabular}{|c|c|c|c|c|c|c|c|c|c|c|c|c|}
\hline \multirow{2}{*}{$\begin{array}{l}\text { Selenium } \\
\text { source }^{1}\end{array}$} & \multicolumn{5}{|c|}{ Selenium levels, mg/kg } & \multirow[t]{2}{*}{ Means } & \multirow[t]{2}{*}{ SEM $^{2}$} & \multicolumn{5}{|l|}{ P-value } \\
\hline & $\overline{0.0}$ & 0.08 & 0.16 & 0.24 & 0.32 & & & Source & Level & $S \times L^{3}$ & $\mathrm{~L}^{4}$ & $Q^{5}$ \\
\hline \multicolumn{13}{|c|}{ Intake, mg/bird } \\
\hline Means & $0.065 \mathrm{E}$ & $0.099 \mathrm{D}$ & $0.139 \mathrm{C}$ & $0.176 \mathrm{~B}$ & $0.210 \mathrm{~A}$ & & 0.003 & 0.794 & $<0.01$ & 0.794 & $<0.01$ & 0.882 \\
\hline SS & $0.067 \mathrm{E}$ & $0.098 \mathrm{D}$ & $0.138 C$ & $0.175 \mathrm{~B}$ & $0.211 \mathrm{~A}$ & 0.138 & & & & & $<0.01^{\mathrm{e}}$ & 0.435 \\
\hline SY & $0.064 \mathrm{E}$ & $0.099 \mathrm{D}$ & $0.141 \mathrm{C}$ & $0.176 \mathrm{~B}$ & 0.209 A & 0.138 & & & & & $<0.01^{\mathrm{e}}$ & 0.321 \\
\hline \multicolumn{13}{|c|}{ Carcass, $\mathrm{mg} / \mathrm{bird}$} \\
\hline Means & $0.050 \mathrm{C}$ & $0.062 \mathrm{BC}$ & $0.073 A B$ & $0.075 \mathrm{AB}$ & $0.082 \mathrm{~A}$ & & 0.006 & 0.118 & $<0.01$ & 0.717 & $<0.01$ & 0.221 \\
\hline SS & 0.046 B & $0.062 \mathrm{AB}$ & $0.073 \mathrm{~A}$ & $0.067 \mathrm{AB}$ & $0.078 \mathrm{~A}$ & 0.065 & & & & & $<0.01^{\mathrm{e}}$ & 0.261 \\
\hline SY & $0.054 \mathrm{~B}$ & $0.062 A B$ & $0.074 \mathrm{AB}$ & $0.083 \mathrm{~A}$ & $0.085 \mathrm{~A}$ & 0.072 & & & & & $<0.01^{\mathrm{e}}$ & 0.539 \\
\hline \multicolumn{13}{|c|}{ Feathers, mg/bird } \\
\hline Means & $0.0015 C$ & $0.0020 B C$ & $0.0023 A B$ & $0.0025 \mathrm{~A}$ & $0.0025 \mathrm{~A}$ & & 0.002 & 0.049 & $<0.01$ & 0.725 & $<0.01$ & $<0.01$ \\
\hline SS & $0.0015 C$ & 0.0018 BC & $0.0022 A B$ & $0.0024 A B$ & $0.0025 \mathrm{~A}$ & 0.0021 & & & & & $<0.01^{\mathrm{e}}$ & 0.331 \\
\hline SY & 0.0015 B & $0.0021 \mathrm{AB}$ & $0.0025 \mathrm{~A}$ & $0.0027 \mathrm{~A}$ & $0.0025 \mathrm{~A}$ & 0.0023 & & & & & $<0.01^{\mathrm{e}}$ & $<0.01$ \\
\hline \multicolumn{13}{|c|}{ Total, mg/bird } \\
\hline Means & $0.051 \mathrm{C}$ & $0.064 \mathrm{BC}$ & $0.077 \mathrm{AB}$ & $0.077 A B$ & $0.084 \mathrm{~A}$ & & 0.006 & 0.136 & $<0.01$ & 0.698 & $<0.01$ & 0.168 \\
\hline SS & $0.047 \mathrm{~B}$ & $0.064 A B$ & $0.077 \mathrm{~A}$ & $0.069 A B$ & $0.081 \mathrm{~A}$ & 0.068 & & & & & $<0.01^{\mathrm{e}}$ & 0.208 \\
\hline SY & 0.055 B & $0.064 \mathrm{~B}$ & $0.077 \mathrm{~A}$ & $0.085 \mathrm{~A}$ & $0.088 \mathrm{~A}$ & 0.074 & & & & & $<0.01^{\mathrm{e}}$ & 0.488 \\
\hline \multicolumn{13}{|c|}{ Retention, $\mathrm{mg} / \mathrm{bird}^{7}$} \\
\hline Means & $0.024 \mathrm{C}$ & $0.037 \mathrm{BC}$ & $0.050 A B$ & $0.050 A B$ & $0.057 \mathrm{~A}$ & & 0.006 & 0.136 & $<0.01$ & 0.698 & $<0.01$ & 0.168 \\
\hline SS & $0.020 \mathrm{~B}$ & $0.037 \mathrm{AB}$ & $0.050 \mathrm{~A}$ & $0.042 \mathrm{AB}$ & $0.054 \mathrm{~A}$ & 0.041 & & & & & $<0.01^{\mathrm{e}}$ & 0.208 \\
\hline SY & 0.028 B & $0.037 \mathrm{AB}$ & $0.050 \mathrm{AB}$ & $0.058 \mathrm{~A}$ & $0.061 \mathrm{~A}$ & 0.047 & & & & & $<0.01^{\mathrm{e}}$ & 0.488 \\
\hline \multicolumn{13}{|l|}{ Balance, \% } \\
\hline Means & 34.1 & 34.0 & 35.3 & 25.6 & 27.4 & & 4.55 & 0.393 & 0.393 & 0.487 & 0.075 & 0.421 \\
\hline SS & 30.3 & 37.0 & 35.8 & 24.0 & 25.8 & 30.6 & & & & & 0.133 & 0.252 \\
\hline SY & 37.9 & 31.1 & 34.7 & 33.2 & 29.0 & 33.2 & & & & & 0.301 & 0.997 \\
\hline $\begin{array}{l}\text { SS sodium } \\
{ }^{2} \text { Standard e } \\
{ }^{3} \text { Interactive } \\
{ }^{4} \text { Linear effe } \\
{ }^{5} \text { Quadratic } \\
{ }^{6} \text { Sum of the } \\
{ }^{7} \text { Whole bod } \\
{ }^{\text {A-B }} \text { Different }\end{array}$ & $\begin{array}{l}\text { ite, } S Y \text { se } \\
\text { ff means } \\
\text { ts betwe } \\
\text { suppleme } \\
\text { of suppl } \\
\text { ontent in } \\
\text { in the bir } \\
\text { rcase lett }\end{array}$ & $\begin{array}{l}\text { um enrich } \\
\text { elenium a } \\
\text { tion selen } \\
\text { entation se } \\
\text { feathers } \\
n \text { the begi } \\
\text { in the sam } \\
\end{array}$ & $\begin{array}{l}\text { east } \\
\text { ace mineral } \\
\text { levels } \\
\text { um levels } \\
\text { carcass } \\
\text { g of the exp } \\
\text { he are differ }\end{array}$ & urces anc & $\begin{array}{l}\mathrm{Se} / \mathrm{kg} \\
5 \%\end{array}$ & & & & & & & \\
\hline
\end{tabular}

equations in the same variable for the two Se sources were observed for the GSH-Px activity, $\mathrm{SeC}, \mathrm{SeF}, \mathrm{SeT}$ as well as SeR (Figs. 1 and 2). When the response to SS was set to $100 \%$, the estimated relative bioavailability of SY were $81,126,117,126$ and $126 \%$ based on the retention variables $\mathrm{SeC}, \mathrm{SeF}, \mathrm{SeT}$ and $\mathrm{SeR}$, respectively, indicating greater SY availability to improve these corresponding parameters.

\section{Discussion}

This experiment was designed to assess the effects of supplemental Se levels, trace minerals sources, and their interaction on the performance, Se retention, antioxidant enzymatic activity, and serum concentration of thyroid hormones of growing broilers chicks.
Selenium has been recognized as a trace element of physiological importance for growing chicks, given its participation in pathways, which include antioxidant responses and hormone secretion [1]. Nonetheless, despite such essentiality, our outcomes revealed that neither supplemental Se level nor Se source (SS and SY) seemed to have a remarkable effect on growing chick performance. Such outcomes support previous research findings that Se supplementation, regardless of the source (inorganic or organic), does not affect broiler performance traits [3, 17-19], but differ from those reported by Choct et al. [2], Cemin et al. [22], and Markovic et al. [27] who observed positive effects of Se supplementation in growing chick BW and/or FCR. Establishing optimal in-feed Se supplementation for growing broilers has been 
Table 4 Effects of dietary selenium levels and sources on selenium tissue concentration of 17-d-old broiler chickens*

\begin{tabular}{|c|c|c|c|c|c|c|c|c|c|c|c|c|}
\hline \multirow{2}{*}{$\begin{array}{l}\text { Selenium } \\
\text { source }^{1}\end{array}$} & \multicolumn{5}{|c|}{ Selenium levels, mg/kg } & \multirow[t]{2}{*}{ Means } & \multirow[t]{2}{*}{ SEM $^{2}$} & \multicolumn{5}{|l|}{ P-value } \\
\hline & 0.0 & 0.08 & 0.16 & 0.24 & 0.32 & & & Source & Level & $S \times L^{3}$ & $L^{4}$ & $Q^{5}$ \\
\hline \multicolumn{13}{|c|}{ Liver, $\mathrm{mg} / \mathrm{kg}$} \\
\hline Means & 1.55 & 1.47 & 1.41 & 1.37 & 1.33 & & 0.06 & 0.288 & 0.504 & 0.185 & 0.074 & 0.764 \\
\hline SS & 1.41 & 1.50 & 1.50 & 1.54 & 1.44 & 1.47 & & & & & 0.790 & 0.600 \\
\hline SY & $1.69 \mathrm{~A}$ & $1.45 \mathrm{AB}$ & $1.36 \mathrm{AB}$ & $1.18 \mathrm{~B}$ & $1.24 \mathrm{AB}$ & 1.38 & & & & & 0.006 & 0.343 \\
\hline \multicolumn{13}{|c|}{ Breast muscle, mg/kg } \\
\hline Means & 0.296 & 0.279 & 0.278 & 0.292 & 0.267 & & 0.08 & 0.311 & 0.516 & 0.501 & 0.293 & 0.999 \\
\hline SS & 0.307 & 0.258 & 0.272 & 0.292 & 0.253 & 0.277 & & & & & 0.214 & 0.700 \\
\hline SY & 0.285 & 0.299 & 0.284 & 0.293 & 0.281 & 0.288 & & & & & 0.811 & 0.700 \\
\hline
\end{tabular}

* Values represented on a dry matter basis

${ }^{1}$ SS sodium selenite, SY selenium enriched-yeast

2 Standard error of means

${ }^{3}$ Interactive effects between selenium and trace minerals sources and selenium levels

${ }^{4}$ Linear effect of supplementation selenium levels

${ }^{5}$ Quadratic effect of supplementation selenium levels

${ }^{A-B}$ Different uppercase letters in the same line are different by Tukey test at $5 \%$

revealed to be particularly challenging, since estimates may be affected by several factors, such as Se source, the concentration and source of the other trace minerals in experimental diets, as well as Se concentration in feed ingredients, which may range to great extent due to Se content in soil [22] In the current research, even though the amount of Se provided by the basal diets was lower than the requirement estimate from NRC [21] for growing chicks $(0.123$ and 0.131 vs. $0.150 \mathrm{mg} \mathrm{Se} / \mathrm{kg})$, such concentrations were sufficient to allow growth rates similar to those in chicks fed the highest Se levels under study. Presumably, the reasons underlying the absence of chick growth response to Se supplementation in the current research may be associated with the redox status of the birds throughout the feeding assay and with residual effects of maternal nutrition on chick storage of Se. Selenium is mainly required as a cofactor for enzymes involved in ROS scavenging, and therefore, the higher the exposure of birds to stressors, the higher the Se requirement for metabolism is expected to be. The stressors commonly highlighted as those of significant impact on poultry redox balance have been inadequate

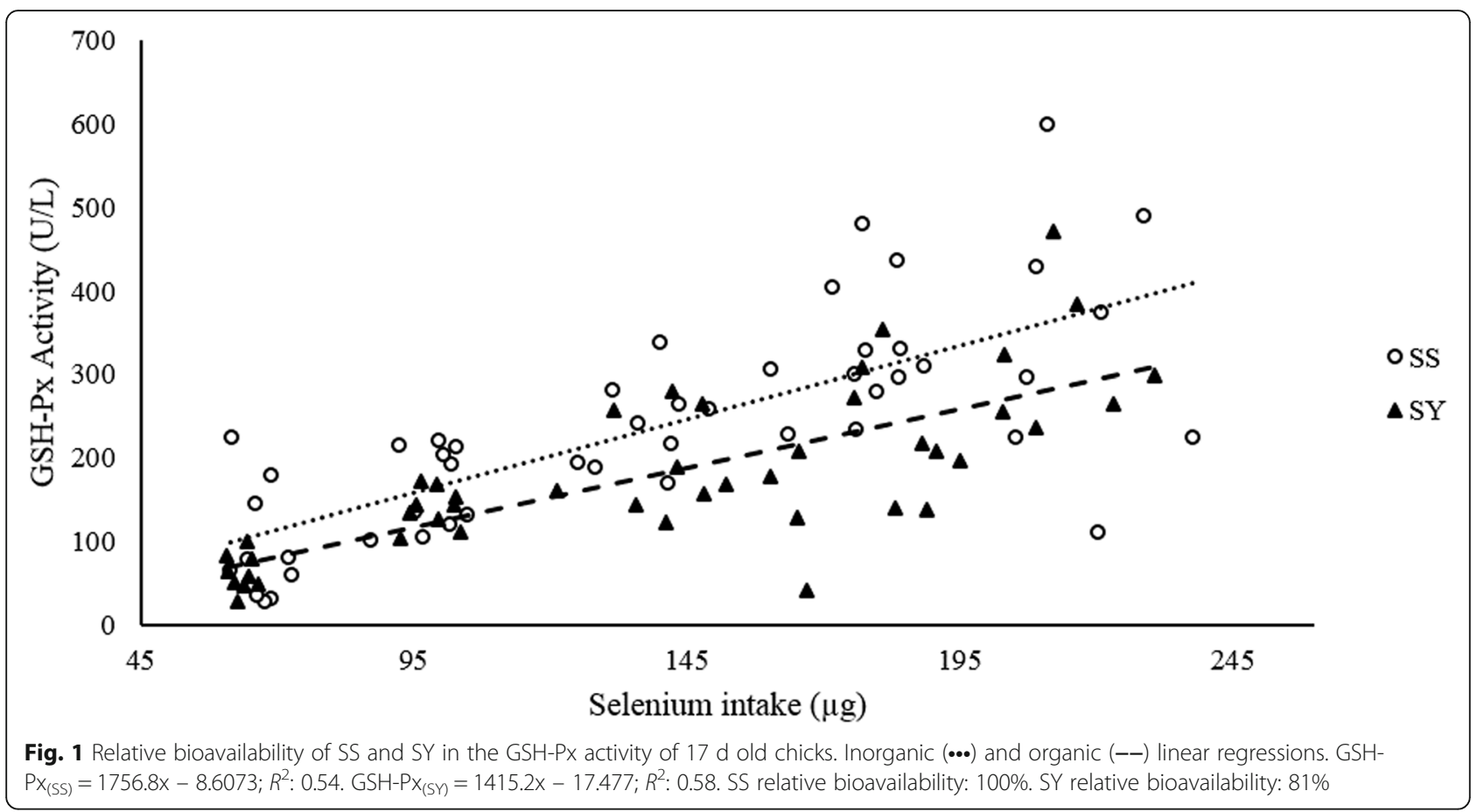




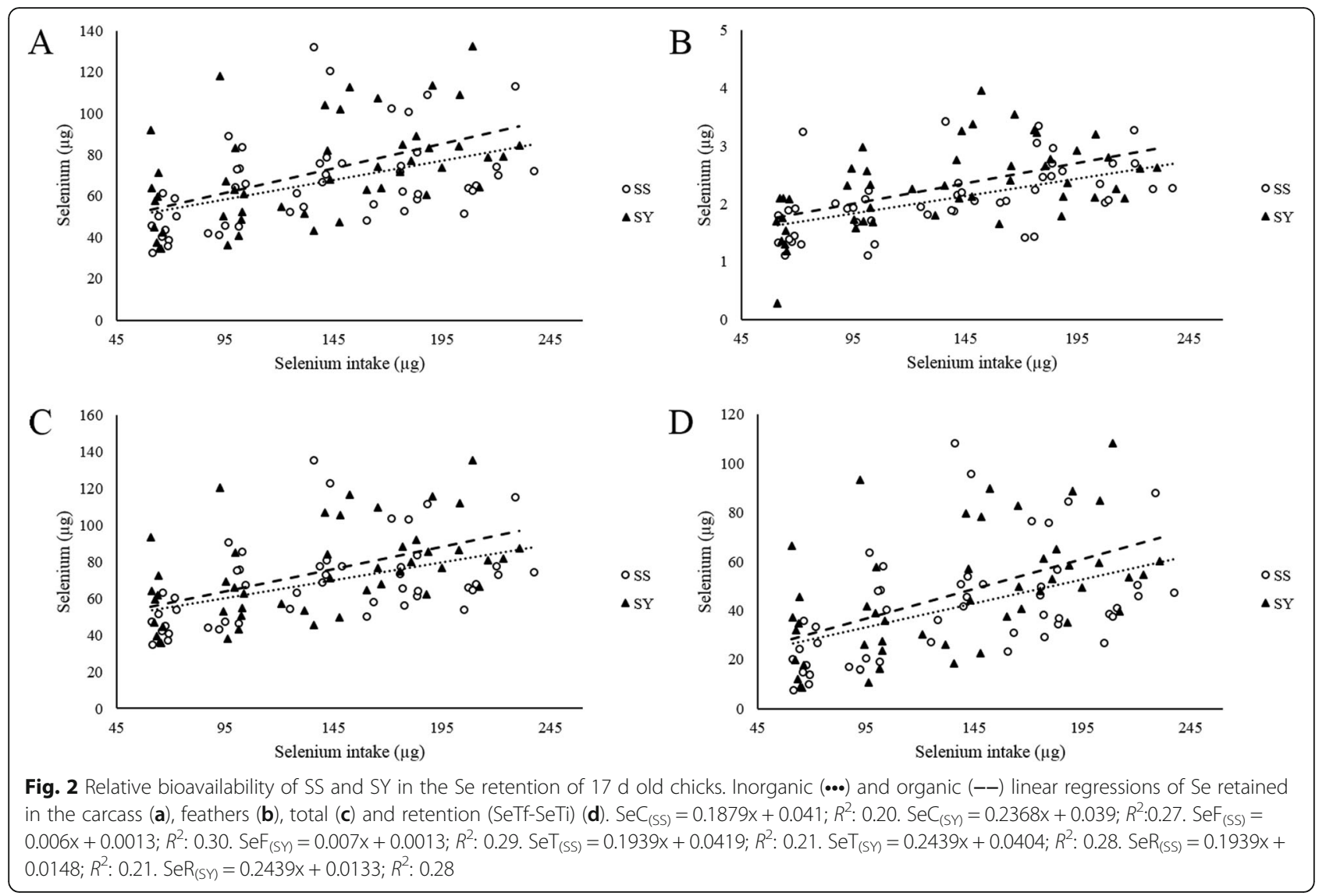

temperature and ventilation, excessive bird handling, high stocking density, sanitary challenges and imbalanced trace mineral nutrition [1]. In the current research, chicks were housed in an environmentally controlled facility and managed according to the genetic strain guideline. Moreover, experimental diets were formulated to meet chick requirements, except for Se, and no clinical signs of sanitary challenge were noticed throughout the assay. Presumably, such experimental conditions avoid the disruption of redox balance in birds, and consequently, minimized the utilization of Se in antioxidant pathways. Another point worth of note, one whose relationship with oxidative stress may influence the Se utilization and the physiological demands for this element, is the age of chicks used in our assay. Because young chicks are not so susceptible to oxidative stress compared with broilers at slaughter age, the metabolic needs for Se are expected to be lower in the starter phase. Finally, Se status of chicks at hatch, influenced by breeder nutrition, as well as Se content of preexperimental diets may have provided enough Se for physiological needs, so the 7-d-experimental period may have been too short to detect nutritional signs of Se deficiency in chicks fed Se-deprived diets. As an attempt of estimating the optimal supplemental Se level for chicks based on growth performance responses, BW and ADG data were fitted to a polynomial regression model, being optimized at 0.133 and $0.130 \mathrm{mg} \mathrm{Se} / \mathrm{kg}$ diet, respectively, in chicks fed Se-Yeast. These estimates are lower than the value described by NRC [21] of $0.15 \mathrm{mg} / \mathrm{kg}$ but similar to the values recommended by Rostagno et al. [28] of $0.138 \mathrm{mg} \mathrm{Se} / \mathrm{kg}$ for organic Se.

As a cofactor for $5^{\prime}$-deiodinase ( $5^{\prime}$-ID), Se participates in the conversion of T4 to the biologically active T3, affecting the metabolism of protein, lipids and carbohydrates $[7,9,10,29]$. The influence of Se on thyroid functioning was well illustrated by Jianhua et al. [6] who noticed a decrease in the synthesis of T3 in chicks fed diets supplemented with iopanoic acid, a monodeiodinase inhibitor, which depresses the hepatic $5^{\prime}$-ID activity. Yet, the authors noticed a negative correlation of T3 plasmatic concentration with chick growth performance. In the current study, a positive relationship was noticed between the thyroid hormones and growth performance. As detailed in Table 2, serum concentration of free T3 of chicks fed SY and organic trace mineral premix exhibited a similar pattern to those noticed for ADG (Table 1). The linear increase in the free T3: free T4 ratio in chicks fed SY supplemented diets indicates an increase in the conversion of free T3 from the inactive free T4. Such 
findings support those reported by Madkour et al. [9] and Wang et al. [10] that noticed higher T3 and low T4 serum concentrations in response to Se supplementation levels and organic Se sources (selenium yeast and dlselenomethionine). The influence of selenium yeast supplementation on the thyroid hormone concentrations agrees with the findings of Upton et al. [8] who reported a possibly more efficient conversion of $\mathrm{T} 4$ into $\mathrm{T} 3$ after selenium yeast supplementation.

Glutathione peroxidase, as well as superoxide dismutase and catalase, is a component of the antioxidant system responsible for neutralizing ROS species, which may potentially damage cells and tissues $[2,5]$. Although organic Se has been considered more bioavailable than inorganic sources when considering GSH-Px activity [5, 26], we noticed that chicks fed diets containing selenium yeast and organic trace minerals exhibited lower values of GSH-Px activity in the blood compared with SS fed chicks (Fig. 1). Our outcomes support previous findings that chicks fed SS supplemented diets exhibited a higher GSH-Px activity in the plasma, kidneys, pancreas and breast muscles compared with birds fed diets containing selenium yeast $[2,3,17,25,30-32]$. Even though after being absorbed in the intestine, either inorganic or organic Se may be used in GSH-Px activation, the sources differ regarding the metabolic pathways necessary to be incorporated into selenoproteins [33, 34]. After absorption, Se from SS is converted in the liver into hydrogen selenide $\left(\mathrm{H}_{2} \mathrm{Se}\right)$, a compound that plays a central role in $\mathrm{Se}$ metabolism. Once formed, $\mathrm{H}_{2} \mathrm{Se}$ may be either methylated and excreted or converted to selenophosphate $\left(\mathrm{HSePO}_{3}{ }^{2-}\right)$, whose Se will be incorporated into tRNA Se-cysteinyl with further translation to selenoproteins, such as GSH-Px [35]. On the other hand, Se-Met present in selenium yeast follows a transsulfuration into Se-Cys through a $\mathrm{B}_{6}$-dependent reaction [36]. Unlike, Se-Met, Se-Cys, a component of GSH-Px enzyme family as well as other selenoproteins (e.g. deiodinases, thioredoxin reductases, selenophosphate synthetase, etc.) cannot be directly incorporated into proteins without being previously converted into $\mathrm{H}_{2} \mathrm{Se}$. Thus, the conversion of Se-Met into $\mathrm{H}_{2} \mathrm{Se}$ requires more steps than selenite, which may explain the lower efficiency of organic Se utilization to produce such selenoproteins, i.e. Se-Cys containing enzymes and proteins.

As detailed in Table 3, the concentration of Se in the feathers of chicks fed selenium yeast were higher than birds fed SS supplemented diets, which suggests that Se provided by the organic source under study, i.e. selenium yeast, were preferably utilized in feather protein synthesis, instead of being used for GSH-Px synthesis. Our findings demonstrated that selenium yeast supplementation increased the content of Se in chick feathers by $9.5 \%$ compared to SS group. These outcomes support those reported by Mahan and Parret [35], Edens et al. [37], Choct et al. [2], Yoon et al. [31] and Couloigner et al. [19]. Similarly, Edens et al. [37] and Choct et al. [2] reported a higher Se retention in selenium yeast fed chicks. Yet, the referred authors correlated such fact with improvements noticed in feathering score, which was addressed to the utilization of Se-Met for the synthesis of keratin, the major structural protein in feathers, skin, beak, and claws [38]. In eukaryote cells, both methionine (Met) and Se-Met are recognized and utilized in the same way since there is not a specific tRNASeMet in cells, which is equivalent to say that the incorporation of Se-Met into bodily proteins is a non-specific event in which Met is replaced by Se-Met happens in tRNAMet during protein synthesis [39].

Although the content of Se in carcasses and feathers, as well the Se retention, were linearly increased as supplemental Se levels increased (Table 3), the sources of Se under study affected only the Se content in feathers. As detailed in Table 3, Se intake was linearly increased as supplemental Se levels increased, which is expected since ADFI was not affected by Se supplementation. We noticed, however, that compared to Se intake responses, Se carcass and feather deposition increased at a lower extent as Se supplementation increased, reaching a plateau phase at $0.160 \mathrm{mg} \mathrm{Se} / \mathrm{mg}$ diet, which was also observed for GSH-Px and thyroid hormone responses. The Se concentration in the tissues is level and source dependent $[19,26,30]$. In the present study, chicks fed diets containing selenium yeast and organic trace minerals exhibited a linear reduction in the liver Se concentration. Liver is the primary Se storage organ and its Se concentration has been used as a criterion to assess the Se status in the body [32]. Dietary Se-Met is not entirely converted into selenoproteins and may be stored in organs with high protein synthesis such as the skeletal muscle, liver and kidney [40], whereas SS cannot be stored in the body [4]. Our data (Table 3) indicate that not only did the Se retained in the broiler chick body increased with the increased Se levels, but also the Se retained in the feathers was greater when birds were fed selenium yeast and organic trace minerals, which suggests that the reduction in the Se concentration in the liver was due to its deposition as methionine in other tissues. Such evidences confirm that SY molecule was preferably utilized as a source of Met instead of Se. In the liver, Met could have different metabolic fates, which include reaching blood stream to be utilized in body and feather protein accretion, remaining in the liver to be used in methyl donor reactions in Met cycle, or finally, being split into carbon skeleton and ammonia, which would be further excreted as uric acid [41]. Although Se is essential for proper liver function, high hepatic concentration of Se may adversely affect hepatocytes. Hao 
et al. [42] noticed an increased hydrogen peroxide production when supplementing broiler diets with $0.62 \mathrm{mg}$ nano-Se/kg, which, in turn, as highlighted by the authors, reflected greater serum concentrations of aspartate transaminase (AST) and alanine transaminase (ALT), enzymes that are biomarkers of hepatic lesions [43, 44]. In turn, Peric et al. [23] observed that when supplied at high levels, SS increased serum concentrations of AST and ALT in broilers compared with selenium yeast fed birds. The enrichment of meat products with Se is desired due to its benefits in the maintenance of redox balance of cells and tissues, which may improve that final quality of meat products. Unexpectedly, our outcomes indicate that neither Se source nor supplemental Se levels influenced Se deposition in chick breast muscle. Conversely, Wang and $\mathrm{Xu}$ [25] and Sevcikova et al. [45] reported an increase in the Se concentration in broiler breast muscle in response to Se supplementation. As highlighted by the referred authors, Briens et al. [26], Sevcikova et al. [45], discrepancies found in literature regarding tissue Se concentration might be explained by the experimental period length, calculation method and analytical method to determine the Se concentration.

The bioavailability of selenium yeast compared with SS is described in Fig. 2. According to the slope ratio between sources, the relative bioavailability of selenium yeast compared with SS for the Se content in carcass, feathers, total and Se retention were, 126, 116, 125 and $125 \%$, respectively. Ammerman et al. [46] defined the term "bioavailability" as the degree to which an ingested nutrient is absorbed and utilized in the metabolism by the animal, so the higher the bioavailability of a given nutrient source, the lower its amount to be supplemented in diets will be. Based on our findings, more SS needs to be included in diets to reproduce similar retention in chick tissues, which is undesired on environmental grounds due to higher excretion rates. Additionally, excessive SS has shown to have pro-oxidant properties and lead to hepatic [42] and intestinal damage [47]. Despite its greater bioavailability, our evidence demonstrates that organic Se in the feathers indicates that the Se-Met from selenium yeast was utilized as a source of Met and/ or Cys rather than Se itself. Because our evidence indicates that organic Se, i.e. selenium yeast, was used as Met for feather proteins, playing therefore a structural role, selenium yeast supplemented diets could have slightly exceeded chick needs for Met.

\section{Conclusions}

To the best of our knowledge, this is the first research conducted to investigate supplemental Se levels and trace mineral sources on growing chick responses, where the other trace minerals had the same nature of the Se source assessed, i.e. organic or inorganic. Irrespective of the source, based on performance traits, the supplemental Se level for growing chicks under the conditions of this study was lower than the requirement estimate of NRC [21]. The ideal level of selenium yeast, provided as $\mathrm{SY}$ in an organic trace mineral mix, for growth was $0.133 \mathrm{mg} \mathrm{Se} / \mathrm{kg}$ diet, whereas for SS, the benefits of its supplementation on growth were not so clear. Selenium, regardless of the source, proved to be important in antioxidant responses and thyroid hormone activation. Selenium utilization by chicks differed between the sources assessed, and outcomes suggested that selenium yeast is less efficiently used in antioxidant pathways compared with SS, but more efficiently retained into bodily proteins. Based on Se storage, SY, provided as Sel-Plex ${ }^{\circ}$, showed a higher relative bioavailability compared to SS.

\section{Methods}

\section{The current study was carried out in compliance with the} ARRIVE guidelines

The procedures involving animal care and use were previously approved by Ethics on Animal Use Committee of the Federal University of Viçosa, Viçosa, Minas Gerais, Brazil, prior to the beginning of the assay (Register number 111/2014).

\section{Birds and husbandry}

A total of five hundred 1-d-old male Cobb 500 chickens were obtained from a local commercial hatchery (Rivelli, Mateus Leme, Brazil) and used in the current assay. From 1 to $7 \mathrm{~d}$ of age, birds were fed a pre-starter diet formulated to meet or exceed Rostagno et al. [28] nutritional recommendations, except for Se, whose dietary supplementation was provided according to the NRC [21]. Throughout the entire pre-experimental period, all chicks had free access to water and feed (mash). At $8 \mathrm{~d}$ of age, chicks were housed in an environmentally controlled room and allotted in a complete randomized design into $0.49 \mathrm{~m} \times 0.27 \mathrm{~m} \times 0.33 \mathrm{~m}$ (length $\mathrm{x}$ height $\mathrm{x}$ width) plastic cages with raised wire floors until the end of the feeding assay. Initial stocking density corresponded to 30.9 chicks $/ \mathrm{m}^{2}$ ). Feed and demineralized water were provided ad libitum throughout the 10-day experimental period. Photoperiod was set at $12 \mathrm{~h}$ natural light $/ 12 \mathrm{~h}$ artificial light. Prior to the experimental period at day 8 of age, all chicks were weighed and assigned to treatment groups so initial body weight $(180.3 \pm 1.18 \mathrm{~g})$ was similar among experimental treatments.

\section{Experimental diets and treatments}

A $2 \times 5$ factorial arrangement was used to investigate the effect of 2 sources of microminerals and Se (as organic and inorganic sources) and 5 Se supplementation levels $(0,0.08,0.16,0.24$, and $0.32 \mathrm{mg} \mathrm{Se} / \mathrm{kg})$. Ten replicate 
cages of 5 chicks were randomly assigned to each of 10 treatment groups. Each cage was considered an experimental unit. Selenium sources included supplemental Se from selenium selenite (SS; 45.85\% Se - Metalloys \& Chemicals commercial Ltda - Cotia, SP) and selenium enriched yeast (SY; $0.2405 \%$ Se - Sel-Plex ${ }^{\circ}$ - Alltech, Maringá, Brazil). Organic trace microminerals were supplied as Bioplex ${ }^{\circ} \mathrm{Fe}$ (15\% Fe), Bioplex $\mathrm{Zn}(15.05 \% \mathrm{Zn})$, Bioplex $^{\circ} \mathrm{Cu}(11.36 \% \mathrm{Cu})$, Bioplex ${ }^{\circ} \mathrm{Mn}(13.86 \% \mathrm{Mn})$, whereas inorganic trace minerals sources included iron sulphate $(21.91 \% \mathrm{Fe})$, zinc sulphate $(22.95 \% \mathrm{Zn})$, copper sulphate $(25.13 \% \mathrm{Cu})$, and manganese sulphate $(30.3 \%$ $\mathrm{Mn})$, and I was added as calcium iodide $(86 \% \mathrm{I})$ in both trace mineral supplements. Therefore, diets containing SS and SY were supplemented with inorganic and organic trace mineral supplements, respectively. A semipurified basal diet, based on casein, albumin, corn, and dextrose (Table 5), was formulated to meet or exceed nutritional requirements of Rostagno et al. [28] for starter broilers (8-21 d of age), except for trace minerals. From the basal diet, 4 different diets were produced.

The 4 diets differed from each other with regard to amount and source of Se supplemented (SS or SY) and to the trace mineral supplemented (organic trace mineral or inorganic trace mineral) as follows: 1) basal diet supplemented with organic trace mineral (BD-OTM) without Se supplementation; 2) basal diet supplemented with organic trace mineral $+0.32 \mathrm{mg} \mathrm{Se} / \mathrm{kg}$ feed supplemented as SY; 3) basal diet supplemented with inorganic trace mineral without Se supplementation; and 4) basal diet supplemented with inorganic trace mineral +0.32 $\mathrm{mg} \mathrm{Se} / \mathrm{kg}$ of feed supplemented as SS. Diets supplemented with organic trace mineral supplement containing supplemental Se at 0 and $0.32 \mathrm{mg} / \mathrm{kg}$ as $\mathrm{SY}$ were mixed to produce five dilution series, which, in turn, resulted in five different organic Se concentrations in diets with organic trace minerals: $0,0.08,0.16,0.24$, and 0.32 $\mathrm{mg} \mathrm{Se} / \mathrm{kg}$ of feed. The same procedure was adopted with diets supplemented with inorganic trace mineral, resulting in the five levels of inorganic Se with inorganic trace minerals and a total of 10 diets. Except for Se, all microminerals were supplied to meet NRC [21] required estimates. Sodium phytate as well as a commercial phytase enzyme were added to the semi-purified diets to simulate practical cereal-based diets. Diets were analyzed for Se content prior to the beginning of the assay through the method described below. In order to ensure the reliability to our data, the commonly accepted as the minimum number of samples were collected as described below.

\section{Performance measurements and tissue mineralization}

The birds were weighed, and the experimental diets were introduced when the birds were 8 days of age. At $17 \mathrm{~d}$ of
Table 5 Nutritional composition of semi purified diets used in experimental period, as-fed basis

\begin{tabular}{|c|c|}
\hline Ingredients & $\mathrm{g} / \mathrm{kg}$ \\
\hline Corn & 300 \\
\hline Albumin $^{a}$ & 120 \\
\hline Starch & 127.4 \\
\hline Dextrose & 134 \\
\hline Casein $^{a}$ & 40 \\
\hline Soy protein isolate & 40 \\
\hline Broken rice & 80 \\
\hline Soybean oil & 20 \\
\hline Cellulose $^{a}$ & 40 \\
\hline Calcium carbonate ${ }^{a}$ & 17.6 \\
\hline Potassium phosphate ${ }^{a}$ & 15.80 \\
\hline Magnesium chloride ${ }^{a}$ & 6.50 \\
\hline Potassium chloride ${ }^{a}$ & 4.68 \\
\hline Choline chloride, 60\% & 3.75 \\
\hline Mixture of amino acids ${ }^{b}$ & 35.55 \\
\hline Micronutrients ${ }^{\complement}$ & 12.65 \\
\hline Microminerals $^{d}$ & 2.00 \\
\hline Phytase $e^{e}$ & 0.10 \\
\hline \multicolumn{2}{|l|}{ Calculated nutrients } \\
\hline AMEn, kcal/kg & 3122 \\
\hline Crude protein ${ }^{f}, \%$ & 22.58 \\
\hline \multicolumn{2}{|l|}{ SID amino acids, $\%$} \\
\hline Lysine, \% & 1,254 \\
\hline Methionine, \% & 0.552 \\
\hline Methionine + Cystine, \% & 0.913 \\
\hline Threonine, \% & 0.831 \\
\hline Calcium ${ }^{f}, \%$ & 0.878 \\
\hline Total Pf $\%$ & 0.581 \\
\hline Available P, \% & 0.420 \\
\hline $\mathrm{Se}^{\mathrm{f}}, \mathrm{mg} / \mathrm{kg}$ & 0.138 \\
\hline
\end{tabular}

a P.A purism reagent exceeds standard ACS specification in trace metals analysis

${ }^{b} 0.03 \%$ L-lysine (79\%); 0.27\% L-arginine (98.5\%); 0.40\% L-glycine (98.5\%); $0.85 \%$ L-alanine (99\%); and 2.0\% L-glutamic acid (99\%). The amino acids alanine, glycine, and glutamic acid were added to maintain the ratio of essential nitrogen to total nitrogen at 0.50

c $0.055 \%$ coccidiostatic; $0.010 \%$ avilamycin; $0.030 \%$ BHT; $1.02 \%$ sodium phytate and $0.150 \%$ vitamin blend supplemented per $\mathrm{kg}$ of feed: vitamin A, $7500 \mathrm{IU}$; vitamin D3, $1900 \mathrm{IU}$; vitamin E, $28 \mathrm{IU}$; vitamin B1,2 mg; vitamin B2, $5 \mathrm{mg}$; vitamin $B 6,1.2 \mathrm{mg}$; vitamin B12, $12 \mathrm{mcg}$; vitamin $\mathrm{K}, 1.5 \mathrm{mg}$; nicotinic acid, 0.03 $\mathrm{mg}$; pantothenic acid, $0.01 \mathrm{mg}$; folic acid, $0.7 \mathrm{mg}$; and biotin, $0.07 \mathrm{mg}$

${ }^{d}$ Trace mineral supplemented per kg of feed: $80 \mathrm{mg} \mathrm{Fe} ; 1 \mathrm{mg} \mathrm{l} ; 60 \mathrm{mg} \mathrm{Mn} ; 40$ $\mathrm{mg} \mathrm{Zn}$; and $10 \mathrm{mg} \mathrm{Cu}$, except for Se added according each experimental treatment as $0 ; 0.08 ; 0.16 ; 0.24$ and $0.32 \mathrm{mg}$ Se. Inorganic trace mineral supplement sources: Ferrous Sulphate (21.91\% Fe), Zinc Sulphate $(22.95 \% \mathrm{Zn})$, Copper Sulphate $(25.13 \% \mathrm{Cu})$, Calcium lodide $(86 \% \mathrm{I})$, Manganese Sulphate $(30.3 \% \mathrm{Mn})$ and Sodium Selenite $(51,6 \% \mathrm{Se})$. Organic trace mineral supplement sources: Bioplex ${ }^{\oplus} \mathrm{Fe}(15 \% \mathrm{Fe})$, Bioplex ${ }^{\oplus} \mathrm{Zn}(15.05 \% \mathrm{Zn})$, Bioplex ${ }^{\oplus} \mathrm{Cu}(11.36 \% \mathrm{Cu})$, Calcium lodide (86\% I), Bioplex ${ }^{\oplus n}(13.86 \% \mathrm{Mn})$, Selplex ${ }^{\circledR}$ selenium enrichedyeast $(0.236 \% \mathrm{Se})$

${ }^{\mathrm{e}}$ Microbial phytase $-600 \mathrm{FTU} / \mathrm{kg}$

${ }^{\mathrm{f}}$ Analyzed value in ingredients 
age, all chicks and feed leftovers from each experimental unit were weighed to determine body weight (BW) and average daily feed intake (ADFI). Average daily gain (ADG) and feed conversion ratio (FCR) were calculated from such data. Mortality rate was also monitored. At the end of the assay, 1 chick per cage (10 birds/treatment) was randomly selected and slaughtered by cervical dislocation. The bird had the liver and left side of breast muscle collected, lyophilized for $72 \mathrm{~h}$ at $-80{ }^{\circ} \mathrm{C}$ under 800 mbar of pressure (Liobras- São Carlos, SP), ground in a ball mill (Tecnal Equipamentos para Laboratório, TE-350, São Paulo, Brazil) and stored for further analysis of Se content [48].

\section{Selenium retention}

At the beginning of the trial, a reference group of ten 8d-old chicks were randomly selected and slaughtered after a $12 \mathrm{~h}$ fasting period (water was provided ad libitum). Similarly, one chick from each experimental unit was randomly selected and slaughtered at the end of the experimental period (17 d of age). Birds were weighed before and after plucking to determine the weight of feathers. The carcasses were frozen in liquid nitrogen and ground in an industrial mixer (Spolu - Benesse do Brasil - Itajobi, SP) and stored for further analysis of Se content. The whole-body Se retention (SeR) and balance (SeBal) were calculated as follows:

$$
\begin{aligned}
& \text { SeR }=\text { SeTf-SeTi, } \\
& \text { SeBal }(\%)=\text { SeR } / \text { SeI } \times 100,
\end{aligned}
$$

where SeTf and SeTi are the Se amount (mg) in the carcass $(\mathrm{SeC})$ and feathers $(\mathrm{SeF})$ at the end and beginning of the experimental period, respectively, and SeI is the Se intake (mg) during the same period.

\section{Selenium concentration in the tissues}

The Se concentration of the feed ingredients, experimental diets and tissues were analyzed at the Mineral Laboratory of the Animal Science Department of the Universidade de São Paulo (São Paulo, SP) following the methodology proposed by Olson et al. [48]. The Se levels of all the ingredients were determined before diet provision to safely estimate the minimum mineral values.

\section{Antioxidant enzymes and hormones concentration}

At the end of the experimental period one animal per cage was randomly selected to collect blood samples through heart puncture. The samples were collect in three tubes, heparinized vacutainer tubes containing $\mathrm{Na}$ heparin to analyze the whole blood activity of GSH-Px, vacutainer tubes containing EDTA to analyze the activity of superoxide dismutase (SOD), and vacutainer serum tubes for the thyroid hormones (T3 and T4) analysis, respectively. The enzymatic activity was determined through the kits of Randox Laboratories Ltda. (County Antrim, UK) Ransel $^{\circledR}$ and Ransod ${ }^{\oplus}$, respectively, following the manufacturer guidelines. Total thyroxine and free and total triiodothyronine in the serum were analyzed at Diagnóstico do Brasil (São José do Rio Preto, SP) laboratory through the immunoassay kits of Beckman Coulter Diagnostics, Access Total T4 ${ }^{\circ}$, Access Free T3 ${ }^{\odot}$ and Access Total $\mathrm{T}^{\circ}$, respectively.

\section{Statistical analysis}

Data were analyzed as a completely randomized design under an incomplete 2-way (source $\mathrm{x}$ levels) factorial assay with inorganic and organic trace minerals supplement without selenium supplementation and Se supplement levels as SY in organic trace minerals supplement and SS in inorganic trace minerals supplement. In this context, given the implied issues of level zero from both sources, the traditional two-way factorial analysis was generalized to a fractional factorial design, which consists in a carefully chosen subset (fraction) under an experimental treatments framework [49]. This approach is easily accomplished by using common statements from PROC MIXED of $\mathrm{SAS}^{\oplus}$ (SAS Institute Inc., Cary, NC) software. According to the previously mentioned analysis, the significance $(P<0.05)$ of source effect (only two levels) was evaluated through F-test; whereas orthogonal contrasts were applied to perform the analysis between linear and quadratic responses of dependent variables in function of increasing Se levels. Also, the effects of Se levels were compared using Tukey's multiple comparison test. The cages average served as the experimental unit for growth performance, while the single chicks (one per cage) served as the experimental unit for tissue mineral contents, retention, thyroid hormone concentration and enzyme activities. Relative bioavailability values of Se as selenium yeast were estimated by slope ratio comparison based on independent linear regressions using SS as the standard source. The regressions were calculated using the supplemental Se intake (adjusted by feed intake during the whole experiment) as the independent variable rather than added Se level. A tendency was considered for P-value between 0.05 and 0.1 .

\footnotetext{
Abbreviations

Se: Selenium; SY: Selenium-yeast; SS: Sodium selenite; BW: Body weight; ADG: Average daily gain; ADFI: Average daily feed intake; FC: Feed conversion; GSH-Px: Glutathione peroxidase; SOD: Superoxide dismutase; SeCys: Selenocysteine; Se-Met: Selenomethionine; ROS: Reactive oxygen species; T4: Thyroxin; fT4: Free T4; T3: Triiodothyronine; fT3: Free T3; NRC: National Research Council; Sel: Selenium intake; SeC: Selenium in the carcass; SeT: Selenium total; SeR: Selenium retention; SeF: Selenim in the feathers; SeBal: Selenium balance; 5'-ID: 5'-deiodinase; $\mathrm{H}_{2} \mathrm{Se}$ : Hydrogen selenide; $\mathrm{HSePO}_{3}{ }^{2-}$ : Selenophosphate
} 


\section{Acknowledgements}

The authors would like to thank Alltech, Inc. (Nicholasville, KY, USA), Fundação de Amparo à Pesquisa do Estado de Minas Gerais (FAPEMIG), Coordenação de Aperfeiçoamento Pessoal de Nível Superior (CAPES), Instituto Nacional de Ciência e Tecnologia de Ciência Animal (INCT-CA) for providing the financial support necessary to conduct the current research.

\section{Authors' contributions}

Conceptualization, M.I.H., J.E.P.; H.S.R.; Methodology, M.I.H., J.E.P., H.S.R.; Software, W.J.A., P.R.A.; F.F.S.; Validation, P.R.A., M.I.H.; Formal Analysis, M.I.H., J.E.P., G.S.V.; Investigation, P.R.A., M.I.H., J.E.P., G.S.V., J.C.L.M., L.F.; Resources, P.R.A., M.I.H., J.E.P., G.S.V.; Data Curation, P.R.A., M.I.H., J.E.P., G.S.V.; F.F.S.; Writing - Original Draft Preparation, P.R.A., M.I.H.; Writing - Review \& Editing, P.R.A., M.I.H., J.E.P., G.S.V.; Visualization, P.R.A., M.I.H., J.E.P., G.S.V.; Supervision, M.I.H., J.E.P., G.S.V.; Project Administration, M.I.H., J.E.P.; Funding acquisition, M.I.H. The author(s) read and approved the final manuscript.

\section{Funding}

This study was financially supported by: Alltech, Inc. (Nicholasville, KY, USA) by financial support grant number 10229/UFV, which was responsible for funding the acquisiton birds, facilites mantainance, ingredients, laboratory analyses; Fundação de Amparo à Pesquisa do Estado de Minas Gerais (FAPE MIG), Coordenação de Aperfeiçoamento Pessoal de Nível Superior (CAPES), Instituto Nacional de Ciência e Tecnologia de Ciência Animal (INCT-CA), with support the Animal Science Departament at Universidade Federal de Viçosa and Master and PhD grants.

\section{Availability of data and materials}

The dataset generated and/or analyzed during the current study is not publicly available since the data is a preliminary part of another study. The data is, however, available from the corresponding author on reasonable request.

\section{Declarations}

\section{Ethics approval and consent to participate}

All animal care and used procedures were approved by the Animal Care and Use Committee of the Universidade Federal de Viçosa (CEUAP, UFV, Viçosa, Brazil) under protocol n. ${ }^{0} 111 / 2014$, prior to the beginning of the trials, including euthanasia by cervical dislocation, where all efforts were made to minimize suffering. Birds were not anesthetized prior to euthanasia. The birds used in the current research were obtained from a local commercial hatchery (Rivelle, Mateus Leme, Minas Gerais State, Brazil). The hatchery is a facility which unique purpose is to obtain profit from the sale of broiler chicks, which may be used either for research or commercial purposes.

\section{Consent for publication}

Not applicable.

\section{Competing interests}

JEP contracts with Alltech, the supplier of the selenium yeast used in this experiment, to supervise this research. The other authors declare that they have no competing interests.

\section{Author details}

'Department of Animal Science, Federal University of Viçosa, Viçosa 36570900, Brazil. ${ }^{2}$ Production Systems, Natural Resources Institute Finland (Luke), 31600 Jokioinen, Finland. ${ }^{3}$ Pettigrew Research Services, Inc., Champaign, IL 61821, USA.

\section{Received: 27 November 2020 Accepted: 22 March 2021} Published online: 09 April 2021

\section{References}

1. Surai PF, Kochish II. Nutritional modulation of the antioxidant capacities in poultry: the case of selenium. Poult Sci. 2019;98(10):4231-9. https://doi.org/1 $0.3382 / \mathrm{ps} /$ pey406.

2. Choct M, Naylor AJ, Reinke N. Selenium supplementation affects broiler growth performance, meat yield and feather coverage. Br Poult Sci. 2004; 45(5):677-83. https://doi.org/10.1080/00071660400006495.
3. Rao SVR, Prakash B, Raju MVLN, Panda AK, Poonam S, Murthy OK. Effect of supplementing organic selenium on performance, carcass traits, oxidative parameters and immune responses in commercial broiler chickens. Asian Austral J Anim. 2013;26(2):247-52. https://doi.org/10.5713/ajas.2012.12299.

4. Surai PF, Fisinin VI. Selenium in poultry breeder nutrition: an update. Anim Feed Sci Tech. 2014;191:1-15. https://doi.org/10.1016/j.anifeedsci.2014.02. 005.

5. Wang YX, Xiao X, Zhan XA. Antagonistic effects of different selenium sources on growth inhibition, oxidative damage, and apoptosis induced by fluorine in broilers. Poult Sci. 2018. https://doi.org/10.3382/ps/pey192.

6. Jianhua $H$, Ohtsuka A, Hayashi K. Selenium influences growth via thyroid hormone status in broiler chickens. Brit J Nutr. 2000;84(5):727-32. https:// doi.org/10.1017/S0007114500002087.

7. Smith JW, Evans AT, Costall B, Smythe JW. Thyroid hormones, brain function and cognition: a brief review. Neurosci Biobehav R. 2002;26(1):45-60. https://doi.org/10.1016/S0149-7634:01)00037-9.

8. Upton JR, Edens FW, Ferket PR. Selenium yeast effect on broiler performance. Int J Poult Sci. 2008;7(8):798-805. https://doi.org/10.3923/ijps.2 008.798.805.

9. Madkour M, Ali HM, Yassein SA, Abdel-Fattah SA, El-Allawy HM, El-Wardany I. Effect of dietary organic selenium supplement on growth and reproductive performance of Japanase quail breeders and their progeny and its relation to antioxidation and thyroid activity. Int J Poult Sci. 2015; 14(6):317-24. https://doi.org/10.3923/ijps.2015.317.324.

10. Wang $Y$, Wang $H$, Zhan $X$. Effects of different dl-selenomethionine and sodium selenite levels on growth performance, immune functions and serum thyroid hormones concentrations in broilers. J Anim Physiol An N. 2015;100(3):431-9. https://doi.org/10.1111/jpn.12396.

11. Patterson EL, Milstrey R, Stokstad ELR. Effect of selenium in preventing exudative diathesis in chicks. Proc Soc Exp Biol Med. 1957;95(4):617-20. https://doi.org/10.3181/00379727-95-23307.

12. Calvert CC, Nesheim MC, Scott ML. Effectiveness of selenium in prevention of nutritional muscular-dystrophy in the chick. Proc Soc Exp Biol Med. 1962; 109(1):16-8. https://doi.org/10.3181/00379727-109-27088.

13. Thompson JN, Scott ML. Role of selenium in the nutrition of the chick. Nutr J. 1969:97(3):335-42. https://doi.org/10.1093/jn/97.3.335.

14. Huang JQ, Li DL, Zhao H, Sun LH, Xia XJ, Wang KN, et al. The selenium deficiency disease exudative diathesis in chicks is associated with downregulation of seven common selenoprotein genes in liver and muscle. Nutr J. 2011;141(9):1605-10. https://doi.org/10.3945/jn.111.145722.

15. Huang JQ, Ren FZ, Jiang $Y Y$, Xiao C, Lei XG. Selenoproteins protect against avian nutritional muscular dystrophy by metabolizing peroxides and regulating redox/apoptotic signaling. Free Radic Biol Med. 2015;83:129-38. https://doi.org/10.1016/j.freeradbiomed.2015.01.033.

16. Huang JQ, Wang YY, Wang QY, Xiao C, Ren FZ, Lei XG. Digital gene expression (DGE) analysis of nutritional pancreatic atrophy of chicks induced by the Se/vitamin E deficiencies. FASEB J. 2016. https://doi.org/10.1096/fa sebj.30.1_supplement.1170.1.

17. Wang $Y$, Zhan $X$, Zhang X, Wu R, Yuan D. Comparison of different forms of dietary selenium supplementation on growth performance, meat quality, selenium deposition, and antioxidant property in broilers. Biol Trace Elem Res. 2010;143(1):261-73. https://doi.org/10.1007/s12011-010-8839-2.

18. Cai SJ, Wu CX, Gong LM, Song T, Wu H, Zhang LY. Effects of nano-selenium on performance, meat quality, immune function, oxidation resistance, and tissue selenium content in broilers. Poult Sci. 2012;91(10):2532-9. https://doi. org/10.3382/ps.2012-02160.

19. Couloigner F, Jlali M, Briens M, Rouffineau F, Geraert PA, Mercier Y. Selenium deposition kinetics of different selenium sources in muscle and feathers of broilers. Poult Sci. 2015;94(11):2708-14. https://doi.org/10.3382/ps/pev282.

20. Surai PF. Re-defining mineral nutrition. In: Taylor-Pickard JA, Tucker LA, editors. . England: Nottingham University Press; 2005. p. 147-75.

21. National Research Council. Nutrient requirements of poultry. 9th ed. Washington, DC: The National Academies Press; 1994. p. 26-34.

22. Cemin HS, Vieira SL, Stefanello C, Kindlein L, Ferreira TZ, Fireman AK. Broiler responses to increasing selenium supplementation using $\mathrm{Zn}-\mathrm{L}$ selenomethionine with special attention to breast myopathies. Poult Sci. 2018;97(5):1832-40. https://doi.org/10.3382/ps/pey001.

23. Peric L, Milosevic N, Zikic D, Kanacki Z, Dzinic N, Nollet $L$, et al. Effect of selenium sources on performance and meat characteristics of broiler chickens. J Appl Poult Res. 2009;18(3):403-9. https://doi.org/10.3382/japr.2 008-00017. 
24. Rayman MP. The use of high-selenium yeast to raise selenium status: how does it measure up? Brit J Nutr. 2004;92(4):557-73. https://doi.org/10.1079/ BJN20041251.

25. Wang $Y B, X u B H$. Effect of different selenium source: sodium selenite and selenium yeast on broiler chickens. Anim Feed Sci Tech. 2008;144(3-4):30614. https://doi.org/10.1016/j.anifeedsci.2007.10.012.

26. Briens M, Mercier Y, Rouffineau F, Vacchina V, Geraert PA. Comparative study of a new organic selenium source $v$ selenium yeast and mineral selenium sources on muscle selenium enrichment and selenium digestibility in broiler chickens. Brit J Nutr. 2012;110(4):617-24. https://doi.org/10.1017/ S0007114512005545.

27. Marković R, Ćirić J, Drljačić A, Šefer D, Jovanović I, Jovanović D, et al. The effects of dietary selenium-yeast level on glutathione peroxidase activity, tissue selenium content, growth performance, and carcass and meat quality of broilers. Poult Sci. 2018;97(8):2861-70. https://doi.org/10.3382/ps/pey117.

28. Rostagno HS, Teixeira Albino LF, Donzele JL, Gomes PC, de Oliveira RF, Lopes DC, et al. In: Rostagno HS, editor. Exigências nutricionais de frangos de corte. In: Tabelas Brasileiras para aves e suinos: Composição de Alimentos e Exigências Nutricionais. 3rd ed. Minas Gerais: Editora UFV; 2011. p. $95-102$.

29. Beckett GJ, Russell A, Nicol F, Sahu P, Wolf CR, Arthur AR. Effect of selenium deficiency on hepatic type I 50 - iodothyronine deiodinase activity and hepatic thyroid hormone levels in rat. Biochem J. 1992;282(2):483-6. https:// doi.org/10.1042/bj2820483

30. Dlouha G, Sevcikova S, Dokoupilova A, Zita L, Heindl J, Skrivan M. Effect of dietary selenium sources on growth performance, breast muscle selenium glutathione peroxidase activity and oxidative stability in broilers. Czech J Anim Sci. 2008;53:6

31. Yoon I, Werner TM, Butler JM. Effect of source and concentration of selenium on growth performance and selenium retention in broiler chickens. Poult Sci. 2007:86(4):727-30. https://doi.org/10.1093/ps/86.4.727.

32. Liao X, Lu L, Li S, Liu S, Zhang L, Wang G, et al. Effects of selenium source and level on growth performance, tissue selenium concentrations, antioxidation, and immune functions of heat-stressed broilers. Biol Trace Elem Res. 2012;150(1-3):158-65. https://doi.org/10.1007/s12011-012-9517-3.

33. Combs GF. Selenium in global food systems. Br J Nutr. 2001:85(5):517-47. https://doi.org/10.1079/BJN2000280.

34. Rayman MP, Infante $H G$, Sargent M. Food-chain selenium and human health: spotlight on speciation. Br J Nutri. 2008;100(2):238-53. https://doi. org/10.1017/S0007114508922522.

35. Mahan DC, Parrett NA. Evaluating the efficacy of selenium-enriched yeast and sodium selenite on tissue selenium retention and serum glutathione peroxidase activity in grower and finisher swine. J Anim Sci. 1996;74(12): 2967-74. https://doi.org/10.2527/1996.74122967x.

36. Dalto DB, Matte JJ. Pyridoxine (vitamin B6) and the glutathione peroxidase system, a link between one-carbon metabolism and antioxidation. Nutrients. 2017;9(3). https://doi.org/10.3390/nu9030189.

37. Edens FW, Parkhurst CR, Havenstein GB, Sefton AE. Housing and selenium influences on feathering in broilers. J Appl Poult Res. 2001;10(2):128-34. https://doi.org/10.1093/japr/10.2.128.

38. Manangi MK, Vazquez-Anon M, Richards JD, Carter S, Buresh RE, Christensen $\mathrm{KD}$. Impact of feeding lower levels of chelated trace minerals versus industry levels of inorganic trace minerals on broiler performance, yield, footpad health, and litter mineral concentration. J Appl Poult Res. 2012; 21(4):881-90. https://doi.org/10.3382/japr.2012-00531.

39. Birringer M, Pilawa S, Flohé L. Trends in selenium biochemistry. Nat Prod Rep. 2002;19(6):693-718. https://doi.org/10.1039/B205802M.

40. Schrauzer GN. Selenomethionine: a review of its nutritional significance, metabolism and toxicity. Nutr J. 2000;130(7):1653-6. https://doi.org/10.1093/ jn/130.7.1653

41. Wang S, Bottje WG, Song Z, Beers K, Vazques-Añon M, Dibner JJ. Uptake of DL-2-hydroxy-4-methylthio-butanoic acid (DL-HMB) in the broiler liver in vivo. Poult Sci. 2001;80(11):1619-24. https://doi.org/10.1093/ps/80.11.1619.

42. Hao X, Ling Q, Hong F. Effects of dietary selenium on the pathological changes and oxidative stress in loach: (Paramisgurnus dabryanus). Fish Physiol. 2014;40(5):1313-23. https://doi.org/10.1007/s10695-014-9926-7.

43. Biasi F, Albano E, Chiarpotto E, Corongiu FP, Pronzato MA, Marinari UM, et al. In vivo and in vitro evidence concerning the role of lipid peroxidation in the mechanism of hepatocyte death due to carbon tetrachloride. Cell Biochem Funct. 1991;9(2):111-8. https://doi.org/10.1002/cbf.290090208.
44. Ashouri S, Keyvanshokooh S, Salati AP, Johari SA, Pasha-Zanoosi H. Effects of different levels of dietary selenium nanoparticles on growth performance, muscle composition, blood biochemical profiles and antioxidant status of common carp: Cyprinus carpio. Aquac. 2015;446:25-9. https://doi.org/10.101 6/j.aquaculture.2015.04.021.

45. Sevcikova S, Skrivan M, Dlouha G, Kouck'y M. The effect of selenium source on the performance and meat quality of broiler chickens. Czech J Anim Sci. 2006:51:10.

46. Ammerman CB, Baker DP. Lewis AJ. In: Ammerman C, Baker D, editors. Bioavailability of nutrients for animals: amino acids, minerals, vitamins. 1st. ed. London: Academic Press; 1995. p. 303-36.

47. Attia YA, Abdalah AA, Zeweil HS, Bovera F, El-Din AT, Araft MA. Effect of inorganic or organic selenium supplementation on productive performance, egg quality and some physiological traits of dual-purpose breeding hens. Czech J Anim Sci. 2010:55:11.

48. Olson OE, Palmer IS, Carr EE. Modification of the official fluorimetric method for selenium in plants. J Assoc Off Anal Chem. 1975;58:1. Available from. https://doi.org/10.1093/jaoac/58.1.117.

49. Box GE, Hunter JS, Hunter WG. Statistics for experimenters: design, innovation, and discovery. 2nd ed. Hoboken, NJ: Wiley; 2005. ISBN 0-47171813-0.

\section{Publisher's Note}

Springer Nature remains neutral with regard to jurisdictional claims in published maps and institutional affiliations.
Ready to submit your research? Choose BMC and benefit from:

- fast, convenient online submission

- thorough peer review by experienced researchers in your field

- rapid publication on acceptance

- support for research data, including large and complex data types

- gold Open Access which fosters wider collaboration and increased citations

- maximum visibility for your research: over $100 \mathrm{M}$ website views per year

At BMC, research is always in progress.

Learn more biomedcentral.com/submissions 